DOI: $10.17516 / 1997-1370-0700$

УДК 82.01/09

\title{
Original Projections of Author's "Self" in Modern Russian and Uzbek Short Story
}

\author{
Saodat E. Kamilova and Yana Yu. Arustamyan* \\ National University of Uzbekistan named after M. Ulugbek \\ Tashkent, Uzbekistan
}

Received 27.09.2020, received in revised form 06.12.2020, accepted 14.12.2020

\begin{abstract}
This article is devoted to the analysis of the short story genre in Russian and Uzbek literature of the late $20^{\text {th }}$ and early $21^{\text {st }}$ centuries, in which a subjectivist-open position in attitude to reality acquires the quality of the leading principle organizing its artistic integrity. The article analyzes the whole layer of works with different realization of the triad "author-narrator-character". These three components of its beginning are connected at one point, the author becomes both the narrator and the protagonist of a literary text. Moreover, either a partial or complete coincidence of the narrator with the author is observed. In such stories, regardless of the object of reflection, the narration is conducted in the first person and is purely subjective. We decided that it was logical to consider them in accordance with one or another specific type of authorship presented. As a result, we have developed a classification of the types of the author's "Self", which is represented by introverted, juvenile- retrospective and lyrical types of the author's "Self" in modern Russian and Uzbek short stories.
\end{abstract}

Keywords: modern Russian and Uzbek literature, genre, short-story, types of author's "Self", "author-narrator-character", introvert type of author's "Self", juvenal-retrospective type of author's "Self", lyrical type of author's "Self".

Research area: philology.

Citation: Kamilova, S.E., Arustamyan, Ya.Yu. (2020). Original projections of author's "Self" in modern Russian and Uzbek short story. J. Sib. Fed. Univ. Humanit. Soc. Sci., 13(12), 2012-2026. DOI: $10.17516 / 1997-1370-0700$.

\footnotetext{
(C) Siberian Federal University. All rights reserved

* Corresponding author E-mail address: kamilova.saod@yandex.com, yana.arustamyan@yandex.com ORCID: 0000-0001-7542-3970 (Kamilova); 0000-0003-1528-7537 (Arustamyan)
} 


\section{Introduction}

The literary process of the late $20^{\text {th }}-$ early $21^{\text {st }}$ centuries in Russia and Uzbekistan has been developing in conditions of permanent indefiniteness and pluralism of ideas, crisis of hierarchies, "risk society", which, in its turn, leads to the transformations of narration means, blurring the limits of literature phenomena as well as relating of literary studies concepts and renovation of forms, styles, and genres.

Nowadays, the leading role in both Russian and Uzbek literature is taken by narrative genres, including novels (major prose) and short stories. It can be obviously noted that there are many more examples of short stories and other literature of small genres than the texts of a larger volume - novels - while the fact that they are distinguished from artistic point of view is also important.

Consequently, the aim of the present research is the revelation of the specificity of author's "Self" and the means of its expression in a modern Russian and Uzbek short story, as well as the characteristics of the types of author's "Self" conditioned by empiric material in a modern Russian and Uzbek short story.

The article analyses the specificity of associative links between different author's categories ('as a category connecting the problems of poetics and problematics on the whole, i.e. the plan of content and the plan of expression' (Kukuyeva, 2009: 4)), a narrator (as a medium of author's perception and the way of thinking/ reflecting the objective reality), and a character (as a medium of certain value orientations).

Some conclusions concerning short story genre have already become axiomatic that allows us to accept them as postulate. However, the problem of revelation of the most essential aspects of genre development of small prose in both Russian and Uzbek literature is still urgent.

\section{Theoretical framework}

Multiple orientation of artistic searches, attempts to re-conceptualize unstable world, the process of 'elaboration of new viewpoint' (Tynyanov, 1979: 240) left certain traces on contemporary genre evolution in both Uzbek and Russian literature. Moreover, as Leyder- man (2010) reasonably noted, genre 'expresses and forms characteristic "world formula", author's perception of world and humans' (Tynyanov, 1979: 167). In other words, genre allows not only observing the peculiarities of literary processes, but also tracing the changes of social-cultural consciousness.

The epoch of the late $20^{\text {th }}$ - early $21^{\text {st }}$ centuries is defined by complexity of social processes, changes and reconstructions in all life spheres, ambiguous evaluation of such changes, struggle against ideas, transformations of understandings related to people and society, attempts to change state system by reforms on the one side, and, on the other side, to impose their will by force (Kamilova, Shirinova, 2018: 31). Such dynamics may serve as a premise of rapid developing of a short story genre. According to Chernyak (2010), who advocates 'The summarization, apocalyptic mood, argument with classical tradition, discussions about a new hero, searches for a language to be adequate to upcoming century - all these are the characteristics of the literature of the turn of the century, which was symbolically squeezed between the words "beginning" and "end". The literature of this period is the time of questions, not answers; it is the period of genre transformations, searches for a new Word' (Chernyak, 2010: 4-5).

We should emphasize a new, special quality of modern epoch: mosaicity, instability, irreducibility to a single global form of reality explanation. Many authors feel uncertain about it. According to a literary reviewer Pustovaya (2015) 'differentiation of author's interests with the elements of epos, blurring of forms and content, layering of a large form is continuing, therefore, any new big text exceeding the volume over the content brings the revolution nearer: the birth of "connection of everything" out of the moment spirit, accumulation of big history in a small prose' (Pustovaya, 2015: 15). Fragmentariness, briefness (as one of the main features of a short story) seem to be spread in objective reality of the late $20^{\text {th }}$ - early $21^{\text {st }}$ centuries. Life was saturated by so many events, which were hard to take in by people's consciousness and perceived fragmentarily with mosaic puzzles that could not be connected 
by definite links. Therefore, only a short story genre could fix general contours of modern life, ideas, "grain" of a character as it is its competence to work with such fragmental and sketchy material.

A review of scientific works devoted to these problematics shows a number of researches characterizing the specificity of a short-story genre within the context of a certain national literature (Brown, Cain, 1997; Kennedy, 1995; Vojvodić, 2017; Kudryavtseva, 2009; Gayfiyeva, 2010; Matizheva, 2008; Panteleeva, 2006; Vladimirova, 2011). Moreover, a short story is analyzed in a general context of creative work of a contemporary writer (Simmons, 1992; Kolesnikoff, 1998; Wall, 1993; Shneidman, 1995; Dowsett, 1990; Haensgen, 2015; Mokrova, 2003; Yefremenkov, 2006; Vershinina, 2011; Pushkar, 2007; Budarina, 2010).

A special interest is paid to the researches devoted to modern Russian prose (Mokrova, 2003; Yefremenkov, 2006; Vershinina, 2011; Pushkar, 2007; Budarina, 2010), which analyze a short story through the context of revelation of characteristic tendencies and general problems of development of prose on the whole. However, the authors do not aim at elaboration of integral picture of development of a short-story genre. The methodology of literary criticism and empiric analysis of the most significant modern short stories through the prism of postulated conceptual models of modern literary process are represented in the works by Kamilova (2018), Ivanova (1988), Remizova (2007), Latinina (2012), and Yermolin (2015). However, the genre of modern short story is still beyond a complex scientific analysis.

In Uzbek literary studies there is also no multi-aspect analysis of poetics of modern national short stories. One of the most recent detailed works devoted to the short-story genre was the research by Vladimirova (2011), who traced a general history of formation to the development of this genre in Uzbek literature. The review of Uzbek short story of the late $20^{\text {th }}$ century was introduced in the multivolume editions "History of Uzbek Literature" edited by Kari-Niyazov (1994) and "Literary Styles and Genres (Theory and History)" edited by
Nazarov (1991), which analyze genre dynamics and reveal its main trends of development and specificity of representation of objective reality through the prism of recognition of the national traditions.

The specified researches, operating by huge factual and theoretical-analytical materials, contain scientific conclusions related to literary processes at the turn of the centuries, including short-story genre, in particular. However, by virtue of different author's aims, a conceptual problem of typology of author's "Self" in short stories of the late $20^{\text {th }}$ - early $21^{\text {st }}$ centuries in Uzbek literary studies remained beyond the mentioned studies.

\section{Statement of the problem}

1. The specifics of the worldview and the nature of the "Myself - world" - correlations in modern Russian and Uzbek short stories allows us to develop and apply a classification of the types of author's "Self".

2. The first type, which we designate as the introverted type of the author's "Self," includes short stories classified by the attraction to subjective meditations of a person who understands the degree of his spiritual helplessness and at the same time resigns to it. The reflecting character has a dual consciousness: on the one hand, he wants to gain freedom, and does not know what to do with this freedom, and therefore, the authors do not actualize the realization of this desire; on the other hand, he tries to avoid any difficulties, and this, in turn, is the main obstacle to liberation, hence the character's obvious dependence on circumstances.

The author's worldview is based on a sense of inferiority, total loneliness, inability to make a conscious choice, self-pity manifested in monologues, diary revelations, depressive meditations, inactive contemplation and a tendency to reflect on any emotion. First-person form is, in fact, practically the only way of self-expression of reflexive consciousness.

3. In stories with a juvenile-retrospective type of the author's "Self", there is the domination of attempts to trace the origins of self-formation, hope either for renewal through children's perceptions of the world, or for over- 
coming the inferiority of one's life, or revelation of ignorance and misunderstanding even himself. Childhood acts as a measure of today's "Self" of writers, for whom a tense conversation with oneself, exposure of oneself, and repentance are perhaps the ways to understand themselves and their time. Children's memories are perceived either as a "lost paradise", or as global loneliness, or as permanent fear, or as a reflection on children's emotions.

4. The third type of the proposed classification is a lyrical type of the author's self, in which the main feature is the lyrical consciousness of the author-storyteller, distinguished by the focus on his inner world, where the issues of a social nature are generalized through the prism of a personal worldview. In short stories of this type of author's "Self," the plot-forming center becomes a certain stream of experiences built up from a variety of feelings, associations, memories, contemplations, and meditations. The classifying signs of this type are associative thinking, alogism, spontaneous change of emotions and moods, chronotopic versatility.

\section{Methods}

The methodology of the present research is defined by the totality of the methods of comparative-typological, comparative-historical, structural-semantic analyses.

Meanwhile, in the classification of author's "Self", represented in modern Russian and Uzbek short stories, the methods of structural-semantic, systematic, and complex analysis of modern Russian and Uzbek short stories within the paradigm of artistic-aesthetic, ethical-philosophic, historical-social, and psychological reality at the turn of the $20^{\text {th }}-21^{\text {st }}$ centuries were applied that presents a wholeness of representation of not only evolutional development of modern literature in both countries, but also perception of epoch on the whole.

The achievement of the declared objectives of the present research is realized through the application of comparative-typological and comparative-historical methods, which allow characterizing each type of the author's "Self" in both Russian and Uzbek small prose; as well as revealing typological features and differences of the analyzed texts.

\section{Discussion}

Summarizing the research experiments and our own observations, it can be stated that the genre dominant of the short story in the frame of literary-artistic tradition in Russian and Uzbek short stories was represented in the following way.

The plan of content: a narrative character of life contemplation in its complexity and variety of rendering of world perception basing on 'thesis-discrete thinking' (Andreev, 1995); demonstration of conflict and high intensity of depiction; inclination to the eternal themes (universal humanistic eternal values are actualized in short stories by revealing their everlasting concepts, which perturb people of different epochs, different generations, and nations), which were argued by Tamarchenko (2004), Fesenko (2008), Halizev (1999), Tomashevskiy (1999), Chernets (1982), Broytman (2004).

The plan of structure: subjective organization, represented in the form of narration in the first or third person singular; organization of space and time conditions, which are of the least volume, contamination of a plot line, a limited number of imagined events, depiction of formed characters (not in development), specification of a portrait, symbolic sense load of landscape images, implications, intonation-speech organization, which are lowering the role of a dialogue as a means of action development in a short story (Halizev, 1999: 233; Boreev, 2003: 339; Ognev, 1978: 5).

The plan of perception: author's genre definition, folkloristic manner of narration: the presence of character-reader, direct appeal from the narrator to the readers (Tomashevskiy, 1999: 193; Gulayev et al., 1970: 311).

The plan of depiction: narration, mediation (stating the ideas), actioning (Halizev, 1999: 233; Boreev, 2003: 339; Ognev, 1978: 5).

Basing on this background the revelation of ethic-psychological constants of development of literary systems in Russian and Uzbek small prose justifies a conciliate quality of dynamic-evolutional shift of inner regulations in conceptual formation of "Myself - World" to the side of subjectivity, which conditioned the change in the triad relations "author - narra- 
tor - character" through a problematic-thematic range.

In other words, contemporary belleslettres texts are defined by specific peculiarities of the world perception and, depending on the character of correlation "Myself - World", proceed from several types of author's "Self".

The first type of author's "Self", following Remizova's (2007) terminology, we symbolically defined as "introverted". A characteristic feature of introverted type of author's worldview, according to Remizova's (2007) apt remark, is 'introverted depression', where 'the main task is to create a psychological self-portrait' (Remizova, 2007: 17).

A typical character as a personality capable of dynamic activities and behavior is substituted by the author-individual closed in himself, his own personal anxiety and "small tragedies", wishing to understand only himself, listening to only his own emotions and feelings. His monologue about himself is the principal means of creation of a literary text. A "sparse character", non-individuality, depersonalization, apathy, loneliness, despondency, and passivity are the classifying features of modern short stories with introverted type of author's "Self". Moreover, the plot in such belles-lettres texts, as a rule, adynamic with a diminished by-plot devoid of definite culmination points.

For example, in the short story by Kleh "The dogs of Polesye" (2000) a free plot construction let the author concentrate attention on the inner world of the main character Freedman. In fact, he is a dog (although there is an episode with a real dog) - a lost soul that could not find his shore and inertly swam across the "river of life". Being devoid of certain individual characteristics, this personage projects his qualities on the surrounding reality, which becomes scrappy and broken into many unconnected pieces. The events of different time span are interspersed in the story: the description of the incident with the dog from "tourists" life alternates with lyrical digression about "aimless sad mood", about the river as a symbol of life with its "changing character", the nightmare with Chicken, included episode with an old woman with her "hopelessness and anguish, when it is too late to know what is over the turn, having spent the whole life near the river". The narration always goes back from the moment of continuing action to different previous time spans that allows constructing reflected objective reality. It is the period of the 1990s when "neophobs and passists", who hated "everything that could be associated with ... Soviet authority", were popular and when tourism became "the means of liberation from social fetters and, probably, from responsibilities"; it was the time of tragedy in Chernobyl when "...funeral allowance was enough to buy two loaves of bread or half-bottle of vodka".

The story conditionally splits up into two parts. The first part is the story about a domestic dog that liked strangers, having felt a twin soul, and wanted to become a stray dog. The second one is the confession of an "age-mate" who was trying to understand the importance of life and himself. It is noticeable, these two parts differ in narrative manners. Thus, the first one differs by imitation of every-day speech, while the second is featured by literary speech, metaphors, and similes.

Compositional grouping of characters is based on the so-called device of doubling: Freedman, Shipboard Physician, Captain, the old woman, and the dog representing author's alter ego. They are united by a desire, but only the desire to leave for somewhere, gain inner freedom, although they do not know what to do with this freedom, why this freedom is needed. This looks like a kind of abstraction, designed to justify their phlegmatism and 'deep moral sleep' (Remizova, 2007). Meanwhile, to be completely fair, the dog still makes an attempt, although unsuccessful, to leave that place with the "tourists". The rest of the characters only languidly think about it. We note the absence of personal names of the characters, as a technique to emphasize their lack of individuality and depersonalization.

In the story a significant place is given to the description of the river. It is perceived as an independent humanized image. This is achieved not only by a scrupulous, detailed description of its character, features of the flow and other "river puzzles", but also by the use of conceptual metaphors that give a symbolic sound to this image: "The river combs its body 
in the floodplains, cleansing of decaying residues and everything that is dumped into it and merges". The river acts as a symbol of eternity, the imperishability of being, and the character first succumbs to that "feeling of the river", which pushes away everything that has been imposed and unnecessary in life, but then hastily moves away from it: "The overwhelmingness of this thought frightened ... and he tried to squeeze out unnecessary sensitivity from his heart, forget about an old woman on the bank, about a girl picked up by a bus, running away in her mother's shoes to the district center for dancing, and about this dog, resembling people so much ..."

The image of a huge Chicken from the Freedman's nightmare is contrasted with a proud and wayward river. A striking symbol of the 1990s was the American broiler chicken, which flooded the entire post-Soviet space, bringing a new ideology with monstrous metamorphoses of life with it. The Chicken chases after the protagonist trying to destroy him or, to be more precise, his soul. So, the dotted line is the material / spiritual antinomy. This is the only moment in the story when, at a subconscious level, the character feels something, however, in the text the main emphasis is on observation, and not on the desire to understand something (at least) in himself or in the surrounding reality. The protagonist (we emphasize once again that he is the author's alter ego) is in contemplative boredom, which he does not try, or perhaps does not want, to overcome. It seems that everything has been obvious to the character for a long time, and there is no need to act, to decide something. Vagrancy, wandering - this is just a way of avoiding the responsibility of a person who is not able to cope with his own life, when the connections between internal and external life are almost fictitious.

In the short story by U. Hamdam (2013) "The River of My Soul" the river symbolizes the eternity, undecayableness of objective reality destroying the programmed life of the protagonist. The author's "Self" can be easily guessed in the system of feelings and thoughts of the acting character, on behalf of whom the narrative is being conducted. However, unlike
Kleh's Freedman, the protagonist from Hamdam's story is trying to adapt to reality. Here the author conveys the emotional state of his alter ego, whose worldview is characteristic for an eternally busy contemporary with obligatory attributes in the form of a to-do list, a car, and a set of responsibilities of the "right" person, albeit painfully aggravated by his love for the river as something true and real. The described pictures of everyday life, depicting the triumph of treasury, programming, racing for the construction of a better life are brought in the story to an extreme degree of generalization, to incredibility, to the grotesque: "... I am constantly puzzling over the daily bustle of a modern person. What a world he created around him, and then he turned into his slave! ... Sisyphus settled in each of us, we are Sisyphus, each of us!". At the same time, the business side of reality, the so-called "prose of life" with red sticks-prohibitions, is opposed to the "feeling of the river", which the character can experience only in his sweet dreams. The protagonist himself admits that he always wanted to change his boring and monotonous life: "For ten years I had been living with such thoughts and, may lightning strike me, if during this time I edited at least one line of my fate. It's not that I didn't want, but the desire remained only desire." Inability to confront the material world, escape for the world of illusions (dream), duality of consciousness, fear of "prohibitions", self-centeredness are the characteristic features of the protagonist in the Hamdam's short story. Sparing no effort and narrative time, he shows in detail, in more detail, how much you could see, understand, learn in the world and in yourself, if you just stop and observe: "The rays of the setting sun mixed with drops of water, coloring them in different colors, in an instant, creating a bright rainbow, I was drunk with happiness, I was dizzy with it. As if for a moment, I again turned into a little boy. Immersed in the colorful world of childhood. I felt majestic and calm, but in the bowels of the strong and stormy water, as if washing away the pain from my heart, and I wanted to scream, as if being crazy." However, in order to stop, one needs extraordinary strength of mind, inner work, courage, in the end. The character is endowed with these 
qualities only in a dream, i.e. theoretically, and this is not enough to be active. Therefore, such a character has only one fate: to remain alone, feeling his own inferiority. The author's increased vulnerability, gloomy inertness and ironic reflection, which leads to the destruction of the internal and external life of the acting character, led to the creation of a certain type of character, called by the Uzbek researcher Khegay (2013) "a capsule-person".

Consequently, short stories with an inverted type of author's "Self" are unified by a tendency to subjective meditations of a person who understands the degree of his spiritual helplessness and at the same time resigns to it.

The rejection of reality, the escape from it into the sphere of personal experiences caused a number of authors to turn to childhood memories in their stories, in which childhood is perceived either as a "lost paradise", or as a desert of global loneliness, or as a space of permanent fear. Sometimes reflection on children's emotion is emphasized. This type of author's "Self" is conditionally designated as juvenile-retrospective.

In this case, the authors, abstracting from today's themselves, remember themselves being as children or adolescents, and this is a memory, an attempt to trace the origins of self-formation, hope or renewal through children's perception of the world, or to overcome the inferiority of their lives, or to reveal ignorance, misunderstanding even himself. Childhood is displayed as a measure of today's "Self" of writers, for whom a tense conversation with oneself, exposure of oneself, repentance, perhaps are the ways to understand themselves and their time.

Meanwhile, in the story of S. Solouh (2003) "Metamorphoses", the theme of childhood, coupled with the theme of time, is perceived as "lost paradise". The world of childhood in its many manifestations, fragmented into individual sounds, colors, sensations, becomes an independent subject of the image. Compositionally, the story resembles the verbal game "to make an elephant out of a fly" i.e. to transform the word "fly" into the word "elephant" within several movements by changing letters one by one. Such a composi- tion, stipulating the author's understanding of the irreversibility of change, allows the reader to see the harmony of the former life, in this case, childhood. The whole story is based on the multidimensionality of the author's perception of life and childhood memories, structurally divided into three parts, each of which is one of the variants of the word game. Thus, in the first part, the word "instant" after six moves turns into the word "hour". These words constitute a single associative series on the theme of "time". Therefore, this part of the story is about the happiest time when the main character, Lesha Kuleshov, was in harmony with himself and with the outside world. The first part does not have any clear plot frame, the story unfolds as a series of memories, as a retrospective. The narration is conducted in the first person; the world is presented through the prism of perception of a nine-year-old child. Not some events, but pictures, impressions, and sensations are remembered: "There is a short and happy moment when everyone is sleeping. The whole world. Except for birds, dogs, and the grandfather"; "Uth and bulwark. Everything you need is in old magazines. Black and white pages smell like summer. Ants. Attic and roof".

Each part of the story is a certain period of growing up of the character; they are divided by a time frame: 1966, 1970, and 1972. From the first part it is clear that Lesha is studying in the third grade ( 9 years), so this is a story about the stages of growing up (childhood - adolescence - youth). Each part has its own world perception, its colors, its own style.

The second part is the largest in volume. Here the "fly" turns into an "elephant" after nine moves. This part moves from episode to episode through reflection and feelings resembling the puzzles of one picture. Elegistic intonation gives the way to bitterness. First love, unrequited feeling, jealousy, pain - this is the whole range of Lesha Kuleshov's world perception. It is noteworthy that the four penultimate puzzles are presented by Igor Toporkov, the rival of the protagonist, and the girl Muse Tarasyan. The change of the narrator allowed us to convey the subtlety of mood, psychological nuances of feelings of adolescents. The as- 
sociative series "fly-elephant" allows us to feel the power of the first feeling, the pain escaping through a groan, the realization that he is "a plump and little boy who does not know how to pull himself up". In this part, there is already history, there is a (albeit weak) plot, consisting of two lines: Lesha and his brother Sasha / Muse and Igor Toporkov. The line of Lesha/ brother Sasha allows us to feel that the main character is no longer interested in children's games, he is not carried away by a fly that has fallen into the box-radio, Lesha wants to "look out the window, look out into the courtyard, where there is a whistle and loud pops". So the space of the hero's worldview is gradually expanding; it is important for him to know how he looks in others' eyes.

The third part of the story "year - century" again returns the reader to an associative series on the subject of time. Here, the concept "year" after seven moves turns into the word "century". The narration becomes more dynamic and richer: Lesha finds a soul mate Ninka Efgrafova, who is not afraid of climbing with him into his grandfather's attic, delving into old magazines, prompting at the lesson.

While the first part begins with a description of the grandfather's house, where the character is absolutely happy, in the finale, the house is sold by parents, and there is no longer room for happiness; the romantic soul confronts a brutal reality.

All three parts of the story are linked together not only by the presence of the main character, but also by amazing details, observations, and sensations. These details are not just the background of the narrative, they are the main thing, i.e. metaphysical paradise, the core of life that was the foundation of being. It was there, in childhood, that everything was true, genuine and pure. The author sets himself a twofold task: on the one hand, to show the gradual expansion of the character's worldview space and his assimilation into the world, and on the other hand, distancing himself from the adult's worldview, to show the child's moving consciousness, ability to be surprised, inner defenselessness and trustfulness to the world. Thus, by demonstrating the inner world of a child, the author takes a detached position, looking, as it were, from the inside and outside, thereby stating an individual's own experience.

Similar motifs can be traced in the story of the Uzbek prose writer Sultan (2012) "The Fish", but here the motive of remorse, interwoven with Quranic motifs, develops into the motive of forgiveness and hope on the one hand, and the loss of illusions, fear of reality on the other. The narrative of naive childhood dreams, the dismayed memory of the past, sin and faith in a miracle compositionally breaks up into several fragments in which monologues are confessed on behalf of the characters. The connecting element of all parts is the fish that was caught from the pond. The author uses a "psychological portrait" of a specific situation, not to show how it really looks, but to provide the characters with the opportunity to see it with their own eyes. And this is where the peculiarity of the author's worldview, who believes that there can be as many viewpoints and "truths" as possible, is shown, because life is an interweaving of complex, incompatible aspirations and desires. The demonstration of different attitude of the characters to the fish allows the author to create a confessional self-characterization, built from pieces of the world outlook of all characters.

Thus, for the youngest son, the fish is a goldfish, "that magic fish" that knows about his dreams, which "when I speak, silently looks. Patiently listens to me up to the end. When it surfaces, the birds singing stops, insects stop chirping. Dragonflies freeze on the stalks of reeds" and, which would "realize all our desires". For the middle son, the fish becomes a necessary sacrifice in the name of love for the mother and her salvation - "Nobody but me knew about the fact that the fish was sent by God," but for the elder one - the opportunity to avenge the hated father and get rid of the pain of childhood memories "Do you remember how I grabbed your hands when you were beating my mother? It is for you! Fry, fry! Remember how you got drunk and turned everything upside down? Having thrown a mattock at me, cut my shoulder, the scar remained, not on my shoulder, in my heart, it is still bleeding!.. For all my life I have never decided to come to you, but I really wanted to lean on your shoulder 
..." However, the worldview and perception of the life of the youngest son is closest to the author. It is not by chance the story begins and ends with his "speeches with himself" (in addition, the third fragment of the text is also presented through the prism of perception of this character). These parts are the most detailed: the depiction of nature, as well as the character's thoughts, are represented here. Against the background of "apricot and nut trees", "tall neat poplars", "itchy wasps", "chirping of dragonflies", "whispering of the wind", he creates his own small, ephemeral, almost illusory space. The world of faith and feeling, where everything is fulfilled, all you need is only to want it. However, this world is destroyed and all that remains is to ask, "What am I to do now? I have so many desires, who should I now tell about them? Only to God? ... Only to God?" Therefore, the motive of loneliness, the tragedy of being, and fear of reality gradually appears.

Therefore, the stories of the abovementioned authors are unified by the peculiarity of the interpretation of childhood memories, based both on a rethinking of classical traditions (the children's world as a moral dominant) and a sense of the disorder and uncertainty of the modern era, which caused an internal personality crisis.

Another type of author's "Self" in the modern short-story genre is designated as lyrical. This term is conditioned by the fact that the "author's prose" of the 1960-1980s, which traditions are somehow refracted in the modern short story, according to most critics (Ivanova, 1988; Halizev, 1999; Darvin et al., 2001), is referred to a kind of lyrical prose. In a number of modern literary texts of small prose, a predominance of the lyrical principle is observed, which is expressed by the lyrical consciousness of the author-narrator, distinguished by focus on his inner world, where the social problems are generalized through the prism of a personal worldview.

Hence, in the story "Frozen Time" by Tarkovskiy (2001), the lyrical beginning is found at each micro level of the text. It is organized in such a way that a tangible focus on objects at the beginning of the text gradually switches to the "inner voice" of the protagonist. The plot of the story is extremely simple: Gosha Poteryaev goes on a New Year's Eve to the neighboring village of Indygino for champagne for his beloved woman and almost freezes, but Valentine saves him in time. The main action takes place in the last part of the story, and the first three parts are a leisurely narration of how the character "drove home from the taiga on a "buran" for the New Year", interspersed with personal memories, experiences, impressions and lyrical digressions. Life in Siberia is presented through the prism of the perception of the main character, the replicas of hunter friends are reproduced by Goshka Poteryaev "from memory"; an improperly direct speech that allows you to wash away the time distance between the event in the story and the plot of the story, focuses the reader on the present state of the protagonist: "... it became fun again, and again the words of Foma recalled: 'Nothing is better than hunting"'. This technique allows us to perceive life experience not as a 'completed past, but as a past that determines the repetition of the present and future' (Tyupa, 2009: 49).

Lyrical digression, mediative thinking in the story begins when the protagonist is left alone with himself. Loneliness gives a rise to a stream of memories, reinforcing his experiences: "The hunters smirked looking at such an aircraft in ridiculous proximity of a warm cabin with electronic appliances and a salon with well-groomed passengers, drinks and snacks to the endless taiga spaces. And Goshka also grinned, remembering his mate"; "He let the woman go," Foma said to him reproachfully and in frustration. Then Gosha just waved his hand ... And really, he just now felt like something important in his life had collapsed." The protagonist's thoughts are interspersed with a poetic description of Siberian nature, which are characteristic of the lyrical style: "The sun was sown tightly through the frosty air, everything was completely sterile, and Goshka, both outside and inside, was also clean and unusually assembled ..."

In the story, the author strongly emphasizes his resemblance to the main character. This is manifested not only by excellent knowledge of the presented material, landscape sketches, features of worldview, poetization of the im- 
ages of hunters, idealization of taiga, Siberia, as an ideal space, where a person is in harmony with himself and the world, but also by the choice of a specific form of storytelling, where the third-person narration is constantly replaced by an internal monologue, or by voicing someone else's speech, which allows you to express a subjective, similar to the author's lyrical perception of the world. Moreover, in the story there is a combination of plot and extra-plot means of reflecting reality with the help of an author's voice, which casts an evaluative character to the text. This is manifested by delight, admiration, and sometimes by an open exclamation: "How great it is to drive up here, fit the "buran" to the Buranovskaya flock, and everyone will be thrown out of the hut, bearded and emaciated, aged during the time apart and red-cheeked children will yell: "well, you have a scent, Goh!", or:"They pour it on Kedrovoy, but he sniffs on Skalnoy!", or:" I soaped myself in the village - it tickled him! ". They climb to shake the hand, hug, peck on the shoulder. How great it is!" Thus, the story gives an emotional attitude and the form of the third person does not interfere, but rather helps the reader to feel that the author, as if lives by the feelings of the character, transferring the feelings of the character to himself. Therefore, it is impossible to distinguish between the author and the protagonist, since they constitute a certain common "substance" of the lyrical perception of reflected reality. In this sense, Remizova (2002) denotes a distinctive feature of the lyrical worldview of the characters of small prose by M. Tarkovskiy (2001) as a "surprise".

We would simply add that in this story surprise is mixed with an internal unconscious search for something "you cannot live without", hence there are the thoughts and inner philosophizing. The author slowly, without edification, gradually leads to the idea that each individual personality is unique in themselves, every moment in life is valuable, how good it would be to stop and "freeze" these happy moments.

Moreover, for modern stories with a lyrical type of author's "Self", a transition from a subjective emotional response to a particular phenomenon of reality and individual philosophical understanding of the world is char- acteristic. If we turn to Uzbek stories with the lyrical type of the author's "Self", then we can find a whole series of both general and differentiating moments in comparison with Russian small prose.

Thus, subjective perception and depiction of reality in stories can be considered as general regularity of the lyrical coloring of small literary texts in both Russian and Uzbek literature. Similar to Russian storytellers, Uzbek writers reproduce in their works their feelings experienced by them, they are interested in the inner world of a contemporary, they strive for frankness and openness in expressing not only their innermost thoughts, but also ideas about ethical standards in modern society.

It should be noted that the lyrical beginning in modern Uzbek stories becomes one of the dominants. Moreover, the theme of patriotism is becoming one of the leading ones in Uzbek stories with a lyrical type of author's "Self". If Russian prose writers reflect this topic in close connection with the historical past of their people, their love for the Motherland is manifested there in revealing the negative aspects of modern reality, in the open rigidity of judgments; then Uzbek narrators reveal it, taking into account the Oriental tradition, but from a modern angle. Departing from didactics, mentoring and open "cheers" of chanting one's land, which was inherent in the Uzbek lyrical stories of the $60-80 \mathrm{~s}$ of the $20^{\text {th }}$ century, the Uzbek writers convey their subjective attitude towards the homeland, try to understand their attitude to the country, to understand what it means to them, and what they mean to it.

In this regard Sultan's (2011) short story "Bowl on the Water" is of undoubted interest, which is a kind of alloy of multi-genre features. This is a "story-sketch", and "story-thought", and "story-meditation" with a strong elegiac beginning, capturing not only instantaneous lyrical experiences, nuances of undetermined feelings, but also a deep, devoted love for the Motherland. All these sound without excessive moralism, the story convinces and wins the reader's attention with a mass of precisely and correctly captured details. The story "Bowl on the Water" is based on the antithesis, the image of the Beloved - the Motherland 
is contrasted with Sea - Strange Land, and the boat on the water is human destiny and "... the cup floats not as it pleases, but according to the will of the water element". This story by Sultan (2011), in fact, is a chain of impressions, observations, and lyrical sketches. The writer appears here as an outstanding, subtle and inspirational master of the landscape, especially "Fergana", with its pure watercolors, halftones and soulfulness. He surprisingly conveys the charm of a summer evening in the village: "like a thin curtain slowly and unhurriedly descends on trees, on supports of vines, on dusty streets, on neatly cleaned fields - it descends quietly and carefully! In some places, in the courtyards you can see families chatting lively at dinner under the yellow light of a lantern hanging on a quince or apple tree branch. The neighbors treat each other with dinner. At the hearth, a clatter of washed dishes which is laid out in places is heard. The smell of clover, milk, the smell of freshly cut mulberry leaves mixed with the aroma of basil growing in the yard is everywhere around." The realistic plasticity of the writing, combined with lyricism, creates an almost musical composition, which is greatly facilitated by the refrain of the sounding lines: "The waves splash and beat against the boat." The colorful, precisely balanced and finely thought over artistic language creates a completely new image of the Motherland, with love for which every word is permeated: “... two people in a boat, which is spinning like a straw among raging waves, are beckoned by the Motherland. Passionate desires and dreams are only about meeting with Her. My beloved, you are the delight of the soul ... I feel with my whole being an inextricable connection with the Beloved, and if she does not exist, I can only perish in this abyss." The blur of the plot, the lack of a dénouement and variable digressions, an open personal and, therefore, subjective attitude of the writer - all that inevitably include an evaluative element, on the one hand, and an independent worldview and feelings, openness and transparency of the author's position, and patriotic pathos, on the other. Consequently, it allows us to define this lyrical story as a "story-meditation", capable of embodying the fate of a person associated with the fate of a people, nation, and state.

\section{Conclusion}

The peculiarity of the short-story genre lies in the fact that it is updated and manifests itself at the moment when the main contradiction, which determines the essence of a person and his time, is only emerging and is in its infancy, is in the air, and the main goal of the story is to capture and demonstrate this contradiction. The short story is one of the first to respond to a change in era, to a "new round" of social development, becoming a "landmark" genre of time, a kind of a reference point in changing the nature of public life.

'The genre is evolving, mutating, remaining unchanged in its essence', as Chernets (Chernets, 1981: 203) states. This indisputable statement allows us to say that in the modern chaotic, often absurd world, the genre of story exists to capture what the author considers to be the moment of authenticity. Brevity, small form, focus (often) on the micro-fragment of objective reality allows readers to reach this point of authenticity.

An important sociocultural shift is also noteworthy: in our time, the audience of the genre is changing, a short story becomes such a genre phenomenon that is addressed to a narrow circle of readers with high literary professionalism. This, for example, explains the unprofitability of published storybooks and the reluctance of publishers to publish story books. However, in our opinion, it is more significant that in the aspect of poetics, the short story turns to the search and experimental direction. With a variety of searches for organizing the narration, there are examples when the form is detached from the content or vice versa, that is, they are problematically compared to each other from the point of view of traditions. As a result, a novel with a substantial capacity of a story and a story with a capacity of a novel are possible. A prose work mutates into a poetic one, and the phenomenon of poetry arises. In modern literature, the practice of "non finito" is widespread, while the limits of the story, diary entries, or posts on the social network are blurred. 
In our opinion, the most important vector of a short story evolution is associated with the special positioning of the modern author. First of all, the author gets the opportunity to choose the subject and the means of narration to a greater extent than before. When mastering modern reality, when the crisis is perceived as the norm, the short story often drifts to the existentially motivated logic of writing. There is subjectivity of the narration. Today, a story is often a verbal imprint of an author's or some abstract "Self".

There is an expansion of the ways of representing a person. We must agree with the judgment made back in 1991 by Leyderman: '... the story is almost the only one of the prosaic genres that has the ability, ... to declare a new concept of personality. And not just to declare, but to outline, make it visually observable and thereby overthrow it with a test of the "whole world" embodied in it by the aesthetic laws of life' (Leyderman, 1991: 241).

In other words, there is a blurring / crisis of the identity of the subject and, in general, subjectivity. The problem of the protagonist is originally posed as well. These features, of course, somehow affect the architecture of a modern short story and indicate that the analysis algorithm of the poetics of a modern short story can be built providing the canonical features and typology of forms (means, methods, and levels), fixation of significant and climax moments (defined as genuine elements of being) are taken into account.

\section{References}

Andreev, A.N. (1995). Tselostnyi analiz literaturnogo proizvedenia [An Integral Analysis of A Literary Text]. Moscow, NMCentre, 144 p.

Boreev, Y.B. (2003). Estetika. Teoriia literatury: entsiklopedicheskii slovar' terminov. [Aesthetics. Theory of Literature: Encyclopedic Dictionary of Terms]. Moscow, AST, 575 p.

Brown, J., Cain, W. (ed) (1997). Ethnicity and the American Short Story. New York, Garland Pub, $272 \mathrm{p}$.

Broytman, S.E. (2004). Teoria khudozhestvennogo diskursa. Teoreticheskaia poetika. [Theory of Literary Discourse. Theoretical Poetics]. Moscow, Academy, 368 p.

Budarina, A.N. (2010). Zhanr rasskaza v tvorchestve A. Kabakova [A Short-Story Genre in A.Kabakov's Literary Work]. In Vestnik TGPU [Bulletin of TSPU], 4 (22), 76-92.

Chernets, L.V. (1981). K metodologii izuchenia literaturnykh zhanrov [To Methodology of Study of Literary Genres]. In Literaturnyj process [Literary Process]. Moscow, 200-215.

Chernets, L.V. (1982). Literaturnye zhanry (Problemy tipologii i poetiki) [Literary Genres (Problems of Typology and Poetics)]. Moscow, MSU Publishing House, $194 \mathrm{p}$.

Chernyak, M.A. (2010). Sovremennaia russkaia literatura: ucheb. posobie [Modern Russian Literature: Manual]. Moscow, Forum: SAGA, 294 p.

Darvin, M.N., Magomedova, D.M., Tamarchenko, N.D., Tyupa, V.I. (2001). Teoria literaturnyh zhanrov [Theory of Literary Genres]. Moscow, Academia, $256 \mathrm{p}$.

Dowsett, C. (1990). Postmodernist Allegory in Contemporary Soviet Literature: Vladimir Makanin's Utrata. In Australian Slavonic and East European studies, 4 (1-2), 21-35.

Fesenko, E.Y. (2008). Teoria literatury: ucheb. posobie dlia vuzov [Literature Theory: Manual for Higher Educational Institutions]. Moscow, Academ, project, Fund “Mir", 336 p.

Gayfiyeva, G.R. (2010). Poetika zhanra rasskaza v tatarskoi proze kontsa XX-nachala XXI veka. $\mathrm{PhD}$ Thesis [Poetics of Short Story Genre in Tatar Prose of the Late $20^{\text {th }}$ - early $21^{s t}$ Century]. Kazan, $171 \mathrm{p}$.

Gulayev, N.A., Bogdanov, A.N., Yudkevich, L.G. (1970). Teoria literatury v sviazi s problemami estetiki [Theory of Literature in Connection with Aesthetic Problems]. Moscow, Visshaya Shkola, 379 p.

Haensgen, S. (2015). Kommerzialisierung der Literatur / Literarisierung der Kommerzes. In Analysen zur Kultur und Gesellschaft im ostlischen Europa, 13, 34-89.

Halizev, V.Y. (1999). Teoria literatury [Literature Theory]. Moscow, Vysshaya shkola, 400 p.

Hamdam, U. (2013). Zabytaia melodia naia [Nai’s Forgotten Melody]. Tashkent, Muharrir, 278 p. 
Ivanova, N. (1988). Tochka zrenia. O proze poslednikh let [Point of View. On the Prose of Last Years]. Moscow, Sovetskii pisatel', 426 p.

Kamilova, S., Shirinova R. (2018). The Specificity of Development of Russian Literary Process. In Opcion, 34 (87-2), 28-39.

Kamilova, S.E. (ed./transl) (2011). Reka dushi moei. Sb. sovremennykh uzbekskikh rasskazov [The River of My Soul. Collection of Modern Uzbek Short Stories]. Tashkent, Adib, 308 p.

Kari-Niyazov, T.N. (ed) (1994). Istoria uzbekskoi literatury [History of Uzbek Literature]. Tashkent, Fan, $420 \mathrm{p}$.

Kennedy, J., Gerald (ed) (1995). Modern American Short Story Sequences. New York, Cambridge UP, $221 \mathrm{p}$.

Khegay, O.C. (2013). Tipologicheskaia priroda "mirovozzrencheskogo inorodtsa ili cheloveka-kapsuly" v mezhkul'turnom postsovetskom prostranstve [Typological Nature of "Worldview Stranger or Capsule-Person" in Cross-Cultural Post Soviet Area]. Tashkent, Muharrir, 162 p.

Kleh, I. (2000). Psy Polesia [The Dogs of Polesye]. In Druzhba narodov [Peoples' Friendship], 7, available at: http://magazines.russ.ru/druzhba/2000/7/kleh.html.

Kolesnikoff, N. (1998). Absurd in Lyudmila Petrushevskaya's Plays. In Russian Literature XLIII, 469-480.

Kudryavtseva, R.A. (2009). Genezis i dinamika poetiki mariiskogo rasskaza v kontekste literatur narodov Povolzh'ia PhD Thesis [Genesis and Dynamic of Poetics of Mari Short Story in the Context of Povolzhye Literature]. Cheboksari, $433 \mathrm{p}$.

Kukuyeva, G.V. (2009). Lingvopoeticheskaia tipologiia tekstov maloi prozy (na materiale rasskazov V. Shukshina). PhD Abstract [Linguistic-Poetic Typology of Small Prose Texts (on the Materials of V.Shukshin's Stories)]. Barnaul, 32 p.

Latinina, A. (2012). Bol'shaia antologiia rasskaza. Zametki o premii imeni Y. Kazakova. [A Great Anthology of a Short Story. Notes on the Y.Kazakov's Award]. In Novii Mir [New World], 3, 166-178.

Leyderman, N.L. (1991). Mezhdu haosom i kosmosom. Rasskaz v kontekste vremeni. [Between the chaos and space. Short stories in the context of time]. In Noviy Mir [New World]. 7, 56-65.

Leyderman, N.L. (2010). Teoriia zhanra [Genre Theory]. In Institut filologicheskikh issledovanii i obrazovatel'nykh strategii "Slovesnik". Yekaterinburg, UrO RAO, 904 p.

Matizheva, A.K. (2008). Novella i rasskaz v adygeiskoi literature 20-90-h godov XX veka. PhD Abstract [Novella and Short Story in Adygei Literature of the 1920s-1990s]. Maykop, $18 \mathrm{p}$.

Mokrova, M.V. (2003). Zhanr rasskaza v tvorchestve B.M. Ekimova: traditsii i novatorstvo. $\mathrm{PhD} \mathrm{Ab}-$ stract [Short Story Genre in B.M.Yekimov's Work: Traditions and Innovation]. Volgograd, $21 \mathrm{p.}$

Nazarov, B.O. (ed) (1991). Adabii turlar va zhanrlar (tarihii va nazariyasiga oid) [Literary Types and Genres (Historical and Theoretical Aspects]. Tashkent, $432 \mathrm{p}$.

Ognev, A.V. (1978). Russkii sovetskii rasskaz 50-70-h godov [Russian Soviet Short Story of the 1950s-1979s]. Moscow, Prosveshchenie, 208 p.

Panteleeva, T.G. (2006). Poetika udmurtskogo rasskaza. PhD Abstract [Poetics of Udmurt Short Story]. Cheboksary, $23 \mathrm{p}$.

Pushkar, T.A. (2007). Tipologiia i poetika zhenskoi prozy: gendernyi aspekt: na materiale rasskazov T. Tolstoi, L. Petrushevskoi, L. Ulitskoi. PhD Thesis [Typology and Poetics of Female Prose: Gender Aspect: on the Material of Short Stories by T. Tolstaya, L. Petrushevskaya, L. Ulitskaya]. Stavropol, $234 \mathrm{p}$.

Pustovaya, V.Y. (2015). Velikaia legkost'. Ocherki kul'turnogo dvizheni'a [Great Ease. Sketches on Cultural Movement]. Moscow, RIPOL Classic, $352 \mathrm{p}$.

Remizova, M. (2002). Opytnoe pole [Experiment Field]. In Druzhba Narodov [Peoples' Friendship], 1, available at: http://magazines.russ.ru/druzhba/2002/1/remiz.html

Remizova, M. (2007). Tol'ko tekst. Postsovetskaia proza i ee otrazhenie v literaturnoi kritike. [Only Text. Post-Soviet Prose and Its Reflection in Literary Critics]. Moscow, Sovpadenie, $447 \mathrm{p}$.

Shneidman, N. (1995). Russian Literature, 1988-1994: The End of Era. Toronto-Buffalo-London: Univ. of Toronto Press. 
Simmons, K. (1992). Plays for the Period of Stagnation: Lyudmila Petrushevskaya and the Theatre of Absurd. In Birmingham Slavonic Monographs, 21, 137-161.

Solouh, S. (2003). Metamorfozi [Metamorphosis]. In Znamya [Banner], 12, available at http://magazines.russ.ru/znamia/2003/12/solouh.html

Sultan, I. (2011). Chasha na vode [Bowl on the Water]. In Sbornik sovremennykh uzbekskikh rasskazov. [Collection of Modern Uzbek Short Stories]. Tashkent, Adib, 308 p.

Sultan, I. (2012). Ryba (Iz serii "Ferganskie rasskazy") [Fish (Series: Fergana Stories)], In Druzhba Narodov [Peoples' Friendship], 9, available at: http://magazines.russ.ru/druzhba/2012/9/s7.html

Tamarchenko N.D. (ed) (2004). Teoriia literatury: Ucheb. posobie [Theory of Literature. Manual]. Moscow, Academia, $513 \mathrm{p}$.

Tarkovskiy, M. (2001). Zamorozhennoe vremia [Frozen Time]. In Nash Sovremennik [Our Contemporary]. 6, available at: https://www.6lib.ru/download/zamorojennoe-vrema-176244.epub

Tomashevskiy, B.V. (1999). Teoria literatury. Poetika: Ucheb. Posobie [Theory of Literature. Poetics: Manual]. Moscow, Aspect Press, 334 p.

Tynyanov, I.N. (1979). Poetika. Istoriia literatury. Kino [Poetics. History of Literature. Cinema]. Moscow, $576 \mathrm{p}$.

Tyupa, V.I. (2009). Analiz khudozhestvennogo teksta [Analysis of a Literary Text]. Moscow, Academia, $336 \mathrm{p}$.

Vershinina, M.A. (2011). Avtor i geroi v proze V. Makanina 1990-2000-h godov. PhD Abstract [Author and Character in the Prose by V.Makanin of the 1990-2000s]. Volgograd, 23 p.

Vladimirova, N.V. (1980). Razvitie zhanra rasskaza v uzbekskoi literature.[Development of Short Story Genre in Uzbek Literature]. Tashkent, $316 \mathrm{p}$.

Vladimirova, N.V. (2011). Razvitie uzbekskoi prozy XX veka i voprosy khudozhestvennogo perevoda [Development of Uzbek Prose of the $20^{\text {th }}$ Century and Problems of Literary Translation]. Tashkent, $160 \mathrm{p}$.

Vojvodić, J. (2017). (Neo)mythological Elements in the Modern Russian Prose (through the Example of "Surgeon" by Marina Stepnova). In Journal of Siberian Federal University. Humanities \& Social Sciences, 5(10), 768-775.

Wall, J. (1993). The Minotaur in the Maze: Remarks on Lyudmila Petrushevskaya. In World Literature Today: A Literatury Quarterly of the University of Oklahoma, 67(1), 125-126.

Yefremenkov, A.S. (2006). Osobennosti psikhologicheskogo analiza v rasskazah V. Makanina 19701990-h godov. PhD Abstract [The Peculiarities of Psychological Analysis in the Short Stories by V. Makanin]. Tver, $19 \mathrm{p}$.

Yermolin, Y. (2015). Mediumy bezvremenia: Literatura v epokhu postmoderna, ili Transavangard. [Mediums of Hard Times: Literature During the Epoch of Post-Modernism, or Transavangard]. Moscow, Vremia, $206 \mathrm{p}$. 


\author{
С.Э. Камилова, Я.Ю.Арустамян \\ Национальный университет Узбекистана имени Мирзо Улугбека \\ Узбекистан, Ташкент
}

\begin{abstract}
Аннотация. Органическое взаимопроникновение и взаимодействие всех составляющих современной художественной системы, важнейшей из которых является категория жанра, определяют специфику развития художественного процесса, жанровую динамику современного литературного процесса. В современной литературе России и Узбекистана ведущую роль играют повествовательные жанры, среди которых ярко выделяется рассказ. Данная статья посвящена анализу жанра рассказа в русской и узбекской литературах конца XX - начала XXI вв., в котором субъективистски открытая позиция по отношению к реальной действительности приобретает качество ведущего принципа, организующего его художественную целостность. Анализируется целый пласт произведений, где триада «автор-повествовательгерой» реализуется иначе. Три составляющих ее начала соединяются в одной точке, автор становится одновременно и рассказчиком, и действующим лицом художественного текста. Причем наблюдается или частичное, или полное совпадение повествователя с автором. В таких рассказах вне зависимости от объекта отражения повествование ведется от первого лица и носит сугубо субъективный характер. Мы решили, что рассматривать их логично в соответствии с той или иной спецификой типа предъявленного авторства. Вследствие чего нами разработана классификация типов авторского «я», которая представлена интровертированным, ювенально-ретроспективным и лирическим типами авторского «я» в современных русских и узбекских рассказах.
\end{abstract}

Ключевые слова: современная литература России и Узбекистана, жанр, рассказ, типы авторского «я», «автор-повествователь-герой», интровертированный тип авторского «я», ювенально-ретроспективный тип авторского «я», лирический тип авторского «я».

Научная специальность: 10.01.00 - литературоведение. 